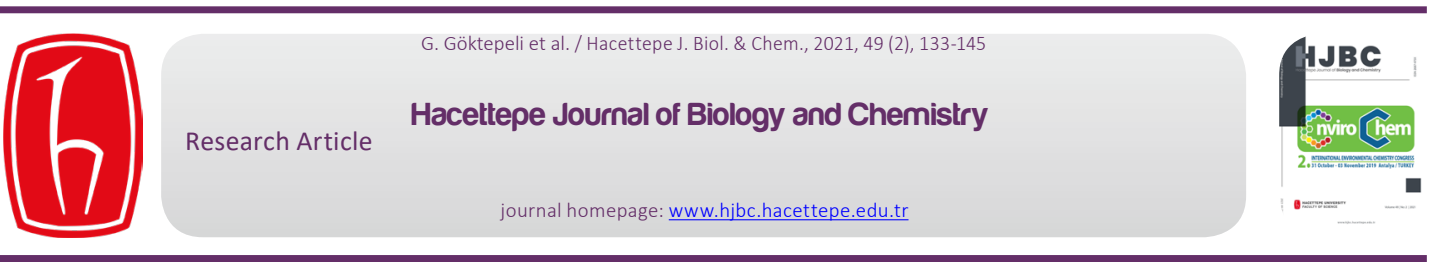

\title{
Phenol Adsorption on Magnetic Biochar Derived From Olive Pomace: Equilibrium, Kinetic and Thermodynamics
}

\section{Pirinadan Elde Edilen Magnetic Biyokömür ile Fenol Adsorpsiyonu: Denge, Kinetik ve Termodinamik}

\author{
Gamze Göktepeli ${ }^{\oplus}$, Sevil Yıldız and Esra Yel ${ }^{*}$ \\ Department of Environmental Engineering, Konya Technical University, Konya, Turkey.
}

\section{ABSTRACT}

n this study, magnetic biochar obtained from pyrolysis of pretreated olive pomace by iron chloride was used as adsorbent to remove phenol and the adsorption capacity of phenol was revealed. Batch experiments were performed as a function of $\mathrm{pH}$, contact time, adsorbent dosage, temperature, and phenol concentration. Moreover, adsorption kinetics and thermodynamics of phenol adsorption onto magnetic biochar were also evaluated in the study. The optimum conditions for maximum adsorption capacity were obtained at $\mathrm{pH}$ of 5.7, dosage of biochar $0.14 \mathrm{~g}$ and 60 minutes contact time. In this study, three adsorption isotherms, namely Langmuir, Freundlich and Temkin, were applied to fit the equilibrium data of adsorption of phenol onto magnetic biochar. Results showed that correlation coefficients $\left(R^{2}\right)$ for three isotherm models decreased with the temperature increment from $20^{\circ} \mathrm{C}$ to $40^{\circ} \mathrm{C}$ and the most suitable isotherm model for adsorption was Freundlich. As for kinetics of the adsorption process, the best described model was found as pseudo-second order. In adsorption thermodynamics part, the negative $\Delta \mathrm{H}^{\circ}$ and $\Delta \mathrm{G}^{\circ}$ values demonstrated that adsorption was exothermic, feasible and was more spontaneous at lower temperatures.

\section{Key Words}

Adsorption, magnetic biochar, olive pomace, phenols.

\section{öz}

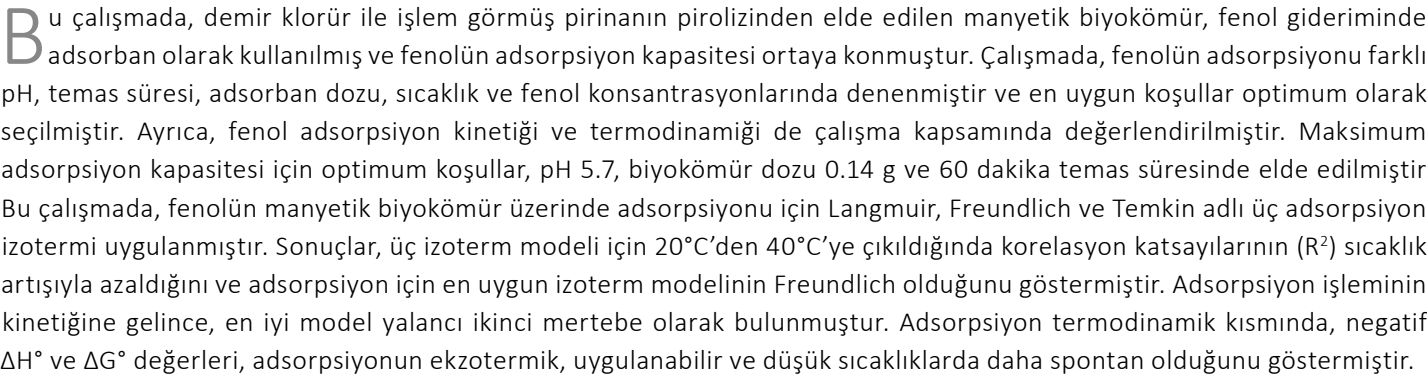

\section{Anahtar Kelimeler}

Adsorpsiyon, magnetik biyokömür, pirina, fenol.

Article History: Received: Feb 11, 2020; Revised: Oct 20, 2020; Accepted: Jan 5, 2021; Available Online: Jan $18,2021$. DOI: https://doi.org/10.15671/hjbc.687387

Correspondence to: E. Yel, Department of Environmental Engineering, Konya Technical University, Konya, Turkey.

E-Mail: gdinc@ktun.edu.tr 


\section{INTRODUCTION}

$n$ recent years, phenolic compounds are becoming indispensable part of our lives since they are being used in many applications. Adhesives, foams, emulsifiers, detergents, insecticides, dyes, explosives etc., includes phenolic compounds and all these products have economic importance in several industries like food, petrochemical, agriculture etc. [1]. However, phenolic compounds are one of the most important toxic compounds for environment and human health also. They are water soluble that means easily reaching to the wastewater through various types of industrial applications. Therefore, phenolic compounds are considered as among priority contaminants in wastewater as even at low concentrations have toxic effects on organisms and human. Capillaries can be damaged if water polluted by phenolic compounds is consumed. Moreover, phenolic compounds' toxicity and resistance into the environment can increase if chlorine, which exist into drinking water, joins to the structure of phenolic compounds [2]. Additionally, phenol compounds are reactive due to chemical reactions either at benzene ring or hydroxyl group and it is highly resistant to biological decomposition due to presence of stable benzene ring [2, 3]. Therefore, it may be accumulated in the tissues before excreting by body metabolic pathway [3].

Different techniques, such as chemical oxidation, biodegradation, membrane filtration, solvent extraction and adsorption, have been adopted for removing phenol from aqueous solutions and/or wastewaters. However, adsorption's low cost, regeneration possibility and high uptake capacity is making it more favored method [4]. Although various adsorbents, either natural or synthetic, have been used in adsorption studies of phenolic compounds, nowadays, adsorbents which are naturally available in the environment are gaining importance by virtue of low-cost [2]. Biochar is carbonaceous solid produced by pyrolysis of biomass at high temperature in oxygen free environment and it can be generated from various agricultural wastes having high production amounts such as fruit wastes, coconut shell, scrap tires, sawdust, rice husk, olive pomace (OP) etc. [5]. It is one of the robust ways for storing carbon which is derived from plants. Furthermore, its potential for water contamination remediation is high since diverse functional groups inhabiting stable porous structure generation can benefit aqueous contaminant removal from solution [6].
Olive pomace (OP) biochar has been used as adsorbent by virtue of its high binding efficiency, low cost and high production amount [7]. OP biochar was used for removal of many different kinds of heavy metal like Ni (II), $\mathrm{Cu}(\mathrm{II}), \mathrm{Pb}(\mathrm{II}), \mathrm{Zn}(\mathrm{II}), \mathrm{Cr}(\mathrm{VI}), \mathrm{Cd}(\mathrm{II})$ and As (III) [7-11]. In addition to removal of heavy metal, these also were used for methylene blue, crystal violet and Remazol brillant blue $R$ dyes $[12,13]$. In a study about pyrolysis char of OP using as adsorbent $[14,15]$, adsorption capacity was found as 8.76, 7.75 and $8.77 \mathrm{mg} \mathrm{g}^{-1}$ for $\mathrm{Pb}$, Zn and $\mathrm{Cu}$, respectively. Although various studies about heavy metal adsorption with OP biochar have been conducted, adsorption of phenolic compounds with OP biochar have not been studied yet. Furthermore, limited number of studies were reported about removal of phenolic compounds by using biochar [5,6,9]. 2,4,6-trichlorophenol was removed from stock solution by biochar produced from sugarcane bagasse and pentachlorophenol was adsorbed by rice straw biochar. Additionally, biochar obtained from pyrolysis of municipal wastewater biosolids were used for removal of halogenated phenols, adsorption capacity of sewage sludge biochar was found high for sulfonated methyl phenols [16]. Biochar obtained from Chinese herb residue [17], pine fruit shells [4] and Hizikia fusiformis [5] are other biochar adsorbents used in phenolic compounds' removal studies in the literature.

There are some modification approaches to increase biochar adsorption capacities; these can be stated as carriage of metals, oxides or ions, mixing biochar with reducing or oxidizing salts, modifying biochar by organic compounds. Among these approaches, magnetic biochar can be successfully generated by chemical co-precipitation of iron oxides and it can provide effective absorptivity, ready separation and easy recycling [6]. There only few studies exist in the literature about adsorption with magnetic biochar and these are mainly about heavy metal adsorption. For instance, Han et al. [6] and Xin et al. [18] studied Cr (VI) adsorption by magnetic biochar derived from peanut hull, Reddy et al. [19] and Yap et al. [20] conducted a study about $\mathrm{Pb}(\mathrm{II})$ and $\mathrm{Cd}$ (II) adsorption with magnetic biochar obtained from pine bark waste and coconut shell. Therefore, in this study, magnetic biochar produced from OP was used as adsorbent to remove phenol and the adsorption capacity of phenol was revealed. Moreover, the effects of contact time, $\mathrm{pH}$, adsorbent dosage, temperature, and phenol concentration were studied to reveal kinetic, thermodynamics and equilibrium characterization of phenol adsorption onto OP magnetic biochar. 


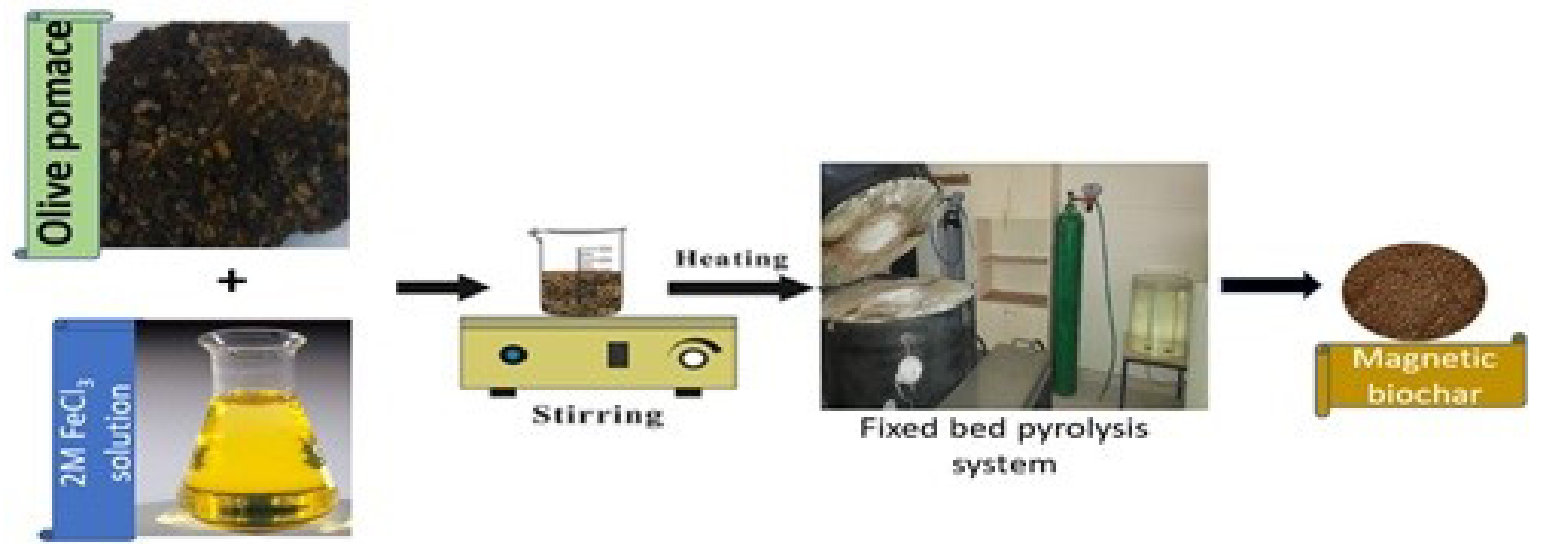

Figure 1. Preparation process of magnetic biochar from OP.

\section{MATERIALS and METHODS}

\section{Preparation of OP char and OP magnetic biochar}

In this study, OP chars and magnetic biochar was obtained from pyrolysis of OP taken from Ernar Inc.-Mersin. Firstly, OP chars were pyrolyzed in fixed bed pyrolysis system at $600^{\circ} \mathrm{C}, 5^{\circ} \mathrm{C} / \mathrm{min}$ heating rate. Secondly, OP magnetic biochars were obtained by following these steps: Firstly, OP samples were dried and grounded and then, $50 \mathrm{~g}$ of dried and grounded OP were mixed in 400 $\mathrm{mL}$ of $2 \mathrm{M}$ iron chloride solution for half an hour and kept at $70^{\circ} \mathrm{C}$ for half an hour (Figure 1). After that, pretreated biomass was then separated from the solution and pyrolyzed at $600^{\circ} \mathrm{C}, 5^{\circ} \mathrm{C} \mathrm{min}-1$ heating rate (Figure 1). By this method, $10 \mathrm{~g} \mathrm{Fe} \mathrm{O}_{3}$ were attached to $1 \mathrm{~g}$ biochar.

\section{Batch adsorption experiments}

Prepared OP chars and $\mathrm{OP} \mathrm{Fe}_{2} \mathrm{O}_{3}$ - magnetic biochars were used in adsorption experiments of the phenols. Firstly, phenol solutions having different concentrations were prepared and measured in accordance with phenol analysis [21] to obtain standard curve. In the phenol analysis, ammonium hydroxide solution, phosphate buffer solution, 4-aminoantipyrine and potassium ferricyanide solution were used and the test results were determined by using spectrophotometry at 500 $\mathrm{nm}$ wavelength.

Secondly, in this study, the effects of different parameters including contact time, initial concentration of phenol, $\mathrm{pH}$ of the solution, adsorbent temperature and the adsorbent dose were investigated and ultimately, the adsorption of isotherms, kinetics and equilibrium were determined. In the decision step of contact time for both OP chars and OP magnetic biochars, 20 $\mathrm{mL}$ phenol solution (initial phenol concentration: $60 \mathrm{mg}$ $\mathrm{L}^{-1}, \mathrm{pH}$ : 5.7 , temperature: $20^{\circ} \mathrm{C}$, adsorbent dosage: $0.1 \mathrm{~g}$ ) were added into beakers and adsorption study of phenol was conducted at $200 \mathrm{rpm}$ and at different contact time (from 10 to 90 min.). In this step, adsorption capacity of OP and OP magnetic biochars were compared to each other to evaluate the effect of applied $\mathrm{FeCl}_{3}$ modification to the OP. In order to evaluate effects of $\mathrm{pH}$ values, adsorption process was conducted with $20 \mathrm{~mL}$ phenol solutions at different $\mathrm{pH}$ values $(2.9,3.6,7,9.4$ and 11.3 ) at selected optimum contact time by keeping other experimental conditions fix. The $\mathrm{pH}$ of the solution was adjusted with $0.1 \mathrm{M}$ hydrochloric acid or 0.1 $\mathrm{M}$ sodium hydroxide. After determination both $\mathrm{pH}$ and contact time, $0.005-0.30 \mathrm{~g}$ adsorbent per $20 \mathrm{~mL}$ were added into beakers including $60 \mathrm{mg} \mathrm{L}^{-1}$ phenol solutions to adjust optimum adsorbent dose. Finally, 20, 30, 40, 50, 60, 70, 80, 90 and $100 \mathrm{mg} \mathrm{L}^{-1}$ initial phenol solution concentrations and effects of temperatures at $20^{\circ} \mathrm{C}$ and $40^{\circ} \mathrm{C}$ were studied at selected contact time, adsorbent dosage and $\mathrm{pH}$ value. 
In this study, the adsorption capacity was determined using the following equation 1 :

$$
\mathrm{q}_{\mathrm{e}}=\frac{(C o-C e) V}{m}
$$

(Equation. 1)

where, qe : adsorption capacity $\left(\mathrm{mg} \mathrm{g}^{-1}\right)$,

$\mathrm{C}_{\mathrm{o}}$ : initial concentration of phenol in the solution $\left(\mathrm{mg} \mathrm{L}^{-1}\right)$,

$C_{e}$ :final equilibrium concentration of phenol $\left(\mathrm{mg} \mathrm{L}^{-1}\right)$,

$V$ : liquid volume inside the reactor $(\mathrm{L})$, and $\mathrm{m}$ is the adsorbent mass (g).

\section{Adsorption isotherms}

Adsorption isotherm reflects the relationship between the amount of a solute adsorbed at constant temperature and its concentration in the equilibrium solution. Moreover, equilibrium study on adsorption provides information on the capacity of the adsorbent; so, they are important for understanding of adsorption system. There are several isotherm equations available for analyzing experimental adsorption equilibrium data. In this study, three adsorption isotherms: Langmuir, Freundlich and Temkin were applied to fit the equilibrium data of adsorption of phenol onto OP magnetic biochar.

\section{Langmuir Isotherm Model}

The one of the most widely used isotherm equation for modeling of the adsorption data is the Langmuir equation, which is valid for monolayer sorption onto a surface with a finite number of identical sites and is given by Equation 2 [22].

$$
\frac{1}{q e}=\frac{1}{q o}+\frac{1}{q o K_{L}} \frac{1}{C e}
$$

(Equation 2)

where, $\mathrm{q}_{0}$ : maximum adsorption capacity $\left(\mathrm{mg} \mathrm{g}^{-1}\right)$,

$K_{L}$ :langmuir equilibrium constant related to the affinity of binding sites and energy of adsorption $\left(\mathrm{L} \mathrm{mg}^{-1}\right)$,

$\mathrm{C}_{\mathrm{e}}$ : equilibrium concentration $\left(\mathrm{mg} \mathrm{L}^{-1}\right)$,

$\mathrm{q}_{e}$ :equilibrium adsorption capacity of adsorbent $\left(\mathrm{mg} \mathrm{g}^{-1}\right)$.

\section{Freundlich Isotherm}

Freundlich Isotherm is mainly indicated adsorption equilibrium of multi-phase adsorption onto surface and is an equation based on sorption on heterogeneous surface. Equation of this isotherm is given by Equation 3 [23].

\section{$\log \mathrm{q}_{\mathrm{e}}=\log K_{F}+(1 / \mathrm{n}) \log C_{e}$}

(Equation 3)

where, $\mathrm{K}_{\mathrm{F}}$ : Freundlich constants indicating adsorption capacity

$\mathrm{n}$ : adsorption intensity constant

\section{Temkin Isotherm}

The Temkin isotherm model contains a factor that explicitly takes into account the adsorbent-adsorbate interactions. The heat of adsorption of all the molecules in the layer would decrease linearly with coverage due to adsorbent-adsorbate interactions. The adsorption is characterized by a uniform distribution of binding energies up to some maximum binding energy. The Temkin adsorption isotherm expression is given by Equation 4 [24].

$$
\mathrm{q}_{\mathrm{e}}=\frac{\mathrm{RT}}{\mathrm{b}} \ln (\mathrm{A})+\frac{\mathrm{RT}}{\mathrm{b}} \ln \left(\mathrm{C}_{\mathrm{e}}\right)
$$

(Equation 4)

where, $\mathrm{B}\left(=\mathrm{RT} \mathrm{b}^{-1}\right)$ : temkin constant related to heat of adsorption,

A: equilibrium binding constant related to maximum binding energy $\left(\mathrm{L} \mathrm{g}^{-1}\right)$,

Ce: equilibrium concentration of phenol $\left(\mathrm{mg} \mathrm{L}^{-1}\right)$,

R: universal gas constant $\left(\mathrm{J} \mathrm{mol}^{-1} \mathrm{~K}^{-1}\right)$,

$\mathrm{T}$ : absolute solution temperature $(\mathrm{K})$. 


\section{RESULTS and DISCUSSION}

\section{Effect of contact time}

Contact time is one of the vital parameters in adsorption studies. In the study, different contact time values at constant initial phenol concentration were tried to find appropriate duration for the removal of phenol (Figure 2). Different phenol removal trends were observed in the case of using OP biochars and OP $\mathrm{Fe}_{2} \mathrm{O}_{3}$ - magnetic biochars (Figure 2). While phenol adsorption on non-modified OP biochars has no regular kinetic stage, phenol adsorption on magnetic biochar was achieved by two stage kinetic behavior. In phenol adsorption process of OP magnetic biochars, firstly, phenol adsorption increased up to 60 minutes, then lower adsorption capacity was observed during 60-90 minutes. Accordingly, it indicates that accessible sites are higher in initial adsorption stage as compared to second stage. In the study, the highest phenol removal capacity and the lowest phenol concentration after adsorption was achieved at $70 \mathrm{~min}$. and $60 \mathrm{~min}$. for OP biochars and OP magnetic biochars, respectively (Figure 2). At the optimum contact times for OP biochars and OP magnetics biochars, adsorption capacity of phenol was found higher in the experiments conducting with OP magnetic biochars (max. qe for OP char:5.1 $\mathrm{mg} \mathrm{g}^{-1}$; max. qe for OP magnetic char:7.06 $\left.\mathrm{mg} \mathrm{g}^{-1}\right)$. Therefore, the optimum contact time was selected as $60 \mathrm{~min}$. and the other experiments were conducted by using OP magnetic biochars.

\section{Effect of initial $\mathrm{pH}$ value of phenol solution}

It is well known fact that $\mathrm{pH}$ has an important role during adsorption since surface charging of magnetic biochar was affected from initial $\mathrm{pH}$ values [4]. Moreover, phenol ionization degree depends on initial $\mathrm{pH}$ of solution [4, 25]. Adsorption capacity based on different $\mathrm{pH}$ values were illustrated (Figure 3). Phenol adsorption increased from pH 2.9 to 5.7; however, it diminished after 5.7 which is original $\mathrm{pH}$ of stock solution. The reason of decrement of phenol adsorption capacity at alkaline $\mathrm{pH}$ values can be connected to electrostatic repulsion between OP magnetic chars' negatively charged surface and $\mathrm{C}_{6} \mathrm{H}_{5} \mathrm{O}^{-}$ions. Furthermore, negative ions on OP magnetic biochar can repress phenol ions' dispersion and phenol adsorption [26, 27]. Therefore, original $\mathrm{pH}$ of the stock phenol solution was selected as optimum $\mathrm{pH}$ for adsorption experiments.

\section{Adsorption Isotherms}

All three isotherms graphs were drawn for both $20^{\circ} \mathrm{C}$ and $40^{\circ} \mathrm{C}$ based on equations given in materials and methods section to calculate both isotherm constant and capacity values (Figure 4 and Table 1). Figure 4 (a), (b), (c) shows the Langmuir, Freundlich and Temkin curves at $20^{\circ} \mathrm{C}$ and Figure 4 (d), (e), (f) shows the Langmuir, Freundlich and Temkin curves at $40^{\circ} \mathrm{C}$ for phenol adsorption onto OP magnetic biochar, respectively. According to $\mathrm{R}^{2}$ values of Langmuir model, the phenol adsorption with OP magnetic biochar was favorable at $20^{\circ} \mathrm{C}$. Moreover, $\mathrm{K}_{\perp}$ values increased with increment of the solution temperature from $20^{\circ} \mathrm{C}$ to $40^{\circ} \mathrm{C}$; therefore, more adsorption of phenol onto OP magnetic biochar has been determined at higher temperature. Although this result can be attributed that the adsorption process is endothermic, $K_{L}$ values alone are not sufficient parameters to explain the relationship between adsorption and temperature [28]. Furthermore, all three isotherms $R^{2}$ values decreased with the increment of temperature (Table 1). As for Freundlich isotherm, while $\mathrm{n}$ value was found smaller than 1 at $20^{\circ} \mathrm{C}$, it was higher than 1 at $40^{\circ} \mathrm{C}$ (Table 1). This result indicates that the adsorption is favorable over the entire ranges of concentration studies at $20^{\circ} \mathrm{C}$, but the adsorption is favorable especially at high concentration for $40^{\circ} \mathrm{C}$ [29]. The value $1 / n$ is a heterogeneity factor and more heterogeneous surface is obtained when $1 / n$ value closes to the zero. Therefore, in this study, surface heterogeneity increased with increasing temperature since lower $1 / \mathrm{n}$ value was obtained at $40^{\circ} \mathrm{C}$ as compared to $20^{\circ} \mathrm{C}$ [30]. In Temkin isotherm, the constant of phenol adsorption, $B$, is directly related to the coverage of phenol onto OP magnetic biochar due to adsorbent-adsorbate interaction. It decreased from 2.89 to 1.10 with the increment of the temperature (Table.1). This can connect that the heat of adsorption of phenol onto OP magnetic biochar decreases with increasing temperature from $20^{\circ} \mathrm{C}$ to $40^{\circ} \mathrm{C}$ and the sorption is exothermic. Furthermore, the $\mathrm{R}^{2}$ value of the Temkin isotherm was lower at $40^{\circ} \mathrm{C}$ as compared to $20^{\circ} \mathrm{C}$. 


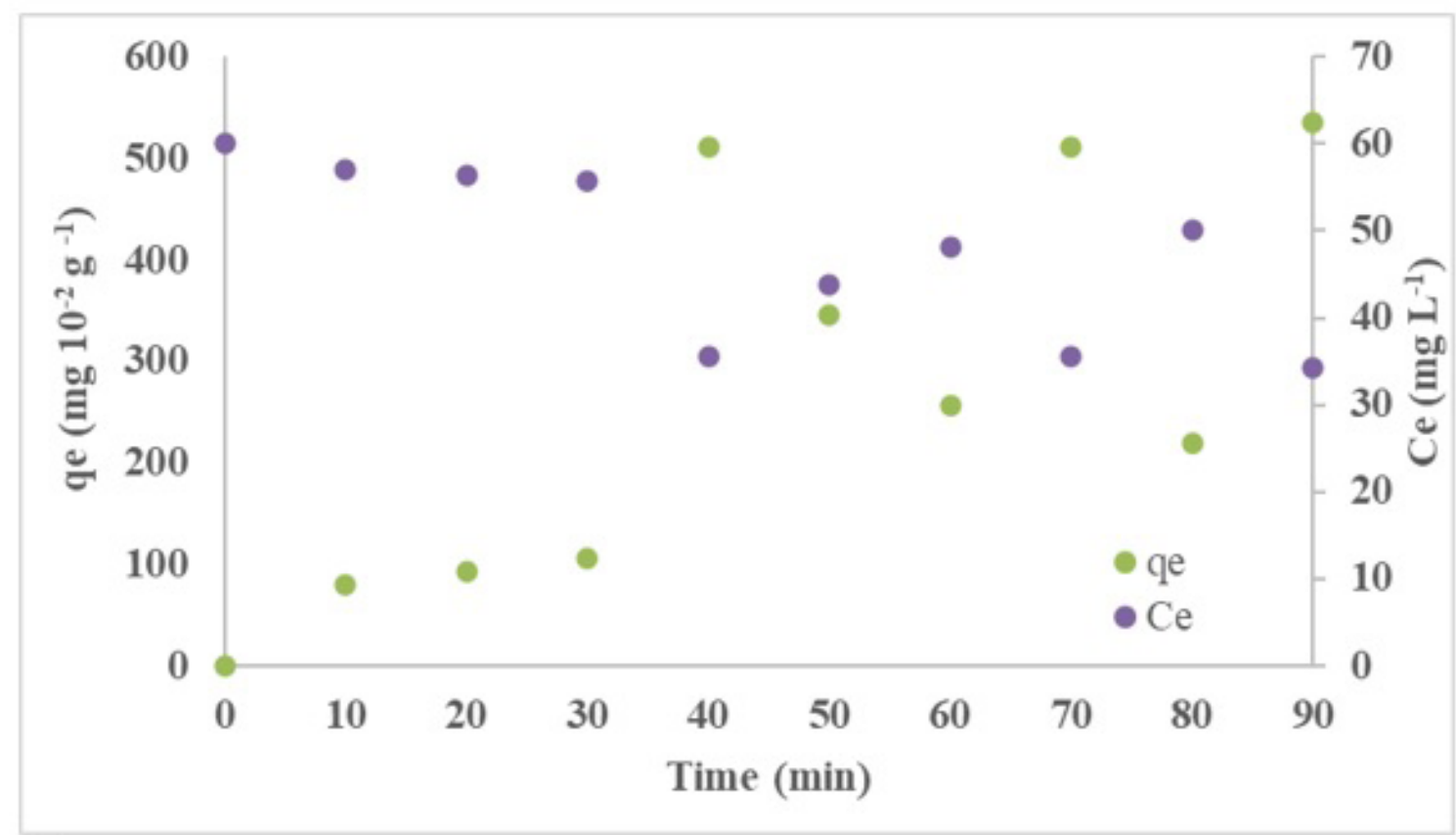

a)

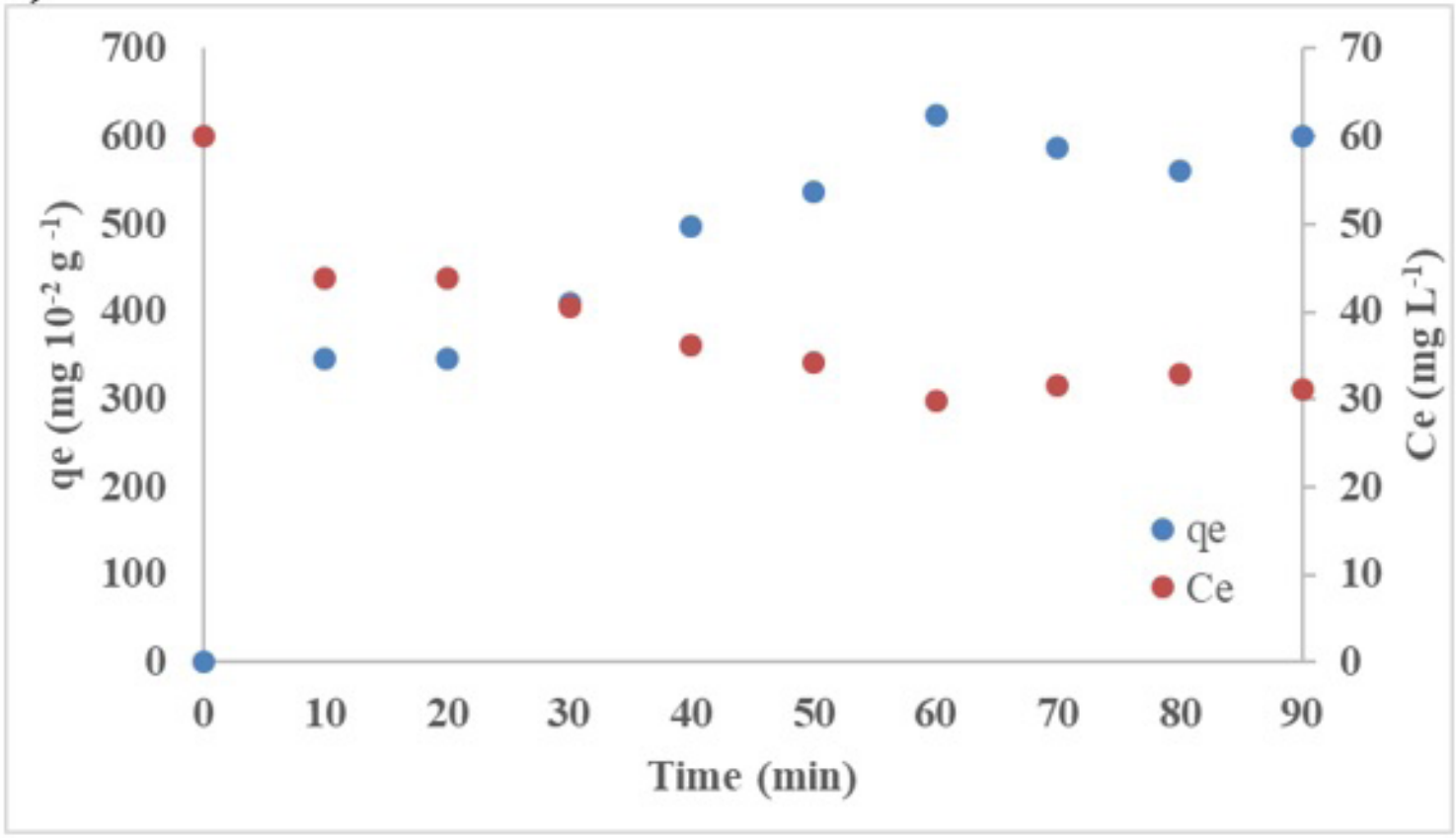

b)

Figure 2. Effect of contact time on phenol adsorption capacity and equilibrium concentration of a) Char b) OP magnetic biochars. 
According to Table.1, when the correlation coefficients of the three isotherm models are compared at $20^{\circ} \mathrm{C}$, the correlation coefficients in three isotherms are high (0.7093,0.9533 and 0.8573). According to these values, the adsorption data are found to be fit Freundlich model at $20^{\circ} \mathrm{C}$. Furthermore, the correlation coefficients of the Freundlich and Temkin isotherms were close to each other. When the temperature was increased from $20^{\circ} \mathrm{C}$ to $40^{\circ} \mathrm{C}$, correlation coefficients for three isotherm models decreased and found as $0.316,0.5326$ and 0.5376 , respectively. Although the highest correlation coefficient at $40^{\circ} \mathrm{C}$ was found for Temkin isotherms, difference between correlation coefficient of Freundlich and Temkin isotherms was not too high (Table 1). Therefore, in this study, the most suitable isotherm model for adsorption of phenol onto OP magnetic biochar can be stated as Freundlich and adsorption process is exothermic. Therefore, lower temperature values are sufficient for phenol adsorption onto OP magnetic biochar since mostly physical forces, like Van der Waals forces, dominate the adsorption process [23]. Moreover, findings in the section of adsorption thermodynamics also supported that phenol adsorption on OP magnetic biochar is exothermic.
Adsorption isotherms were carried out by varying the initial concentration of the adsorbate from 20 to 100 $m g L^{-1}$. Figure 5 (a) and (b), illustrates the equilibrium isotherms of adsorption phenol onto OP magnetic biochar, which describes the specific relationship between the adsorption capacity of adsorbent and the solution concentration of phenol at $20^{\circ} \mathrm{C}$ and $40^{\circ} \mathrm{C}$.

Adsorption capacity, decreased with increase of the temperature. This phenomenon can be explained that the active binding sites were damaged and the binding forces between the phenol molecules and OP were weaken [31]. In this case, the tendency of the qe - Ce graph drawn at $20^{\circ} \mathrm{C}$ is more favorable than $40^{\circ} \mathrm{C}$, suggesting that the mechanism can be exothermic.

\section{Adsorption Kinetics}

The study of adsorption kinetics study is important to understand the behavior of adsorbate adsorption on adsorbent, and to contribute to economical adsorption technology. Kinetic models are used to examine the rate of the adsorption process and potential rate-controlling step. In this study, the kinetic data obtained from batch studies have been analyzed by using pseudo-first order and pseudo-second order models.

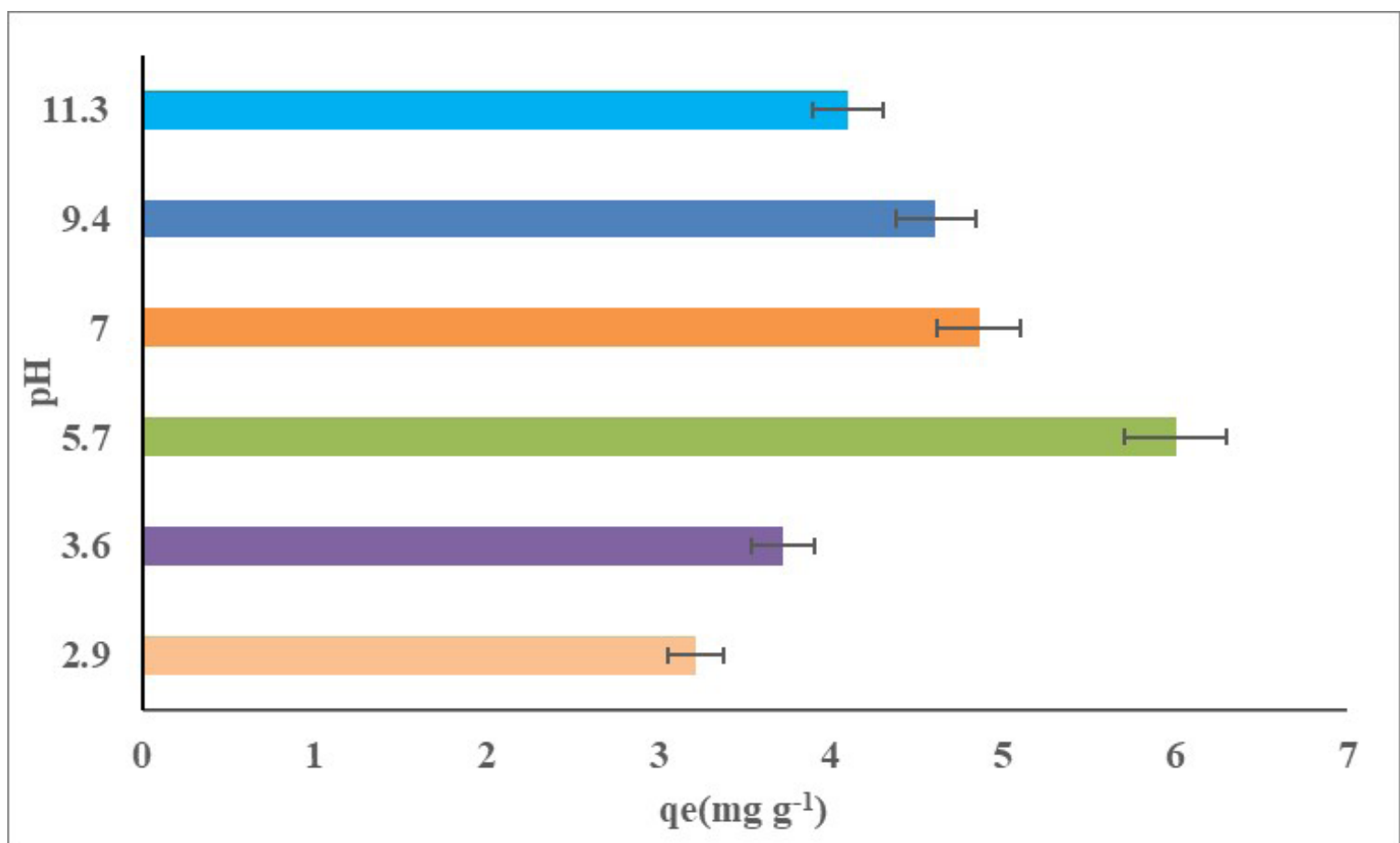

Figure 3. Adsorption capacity of OP magnetic biochar with respect to different initial pH values. 
The pseudo-first order equation of Lagergren is expressed as follows [32]:

$$
\ln \left(\mathrm{q}_{\mathrm{e}}-\mathrm{q}\right)=\ln \mathrm{q}_{\mathrm{e}}-\mathrm{k}_{1} \mathrm{t}
$$

(Equation 5)

where q: amounts of phenol adsorbed (mg geq-1) at equilibrium and at time $t$ ( $\mathrm{min}$ ),

$k_{1}$ : the rate constant of pseudo-first-order sorption $\left(\min ^{-1}\right)$.

The pseudo-second-order kinetic rate equation is expressed as follows [33]

$$
\frac{t}{q}=\frac{1}{k_{2} \mathrm{qe}^{2}}+\frac{1}{q e} \mathrm{t}
$$

(Equation 6)

where $\mathrm{k}_{2}$ :rate constant of pseudo-second order sorption $\left(\mathrm{g} \mathrm{mg}^{-1} \mathrm{~min}^{-1}\right)$.

The graphs of linearized form of the pseudo first and second order equations were shown in Figure 6 (a-b). Moreover, rate constants and phenol adsorption capacities for both adsorption kinetics were given at Table 2. Results showed that the pseudo-second order equation provided better correlation for the adsorption data since $R^{2}$ value were higher at this kinetic. Moreover, obtained results in this study also matched with other studies about phenol adsorption in the literature [2-6]. Kinetic data followed closely to the pseudo-secondorder model for phenol adsorption with both water hyacinth ash and biochar prepared from the pine fruit shells $[3,6]$. Accordingly, the qe values were calculated based on equation in Figure 6 and they found as 4.58 and $7.06 \mathrm{mg} \mathrm{g}^{-1}$ for pseudo first and second order kinetic models, respectively.

\section{Adsorption Thermodynamics}

Thermodynamic parameters such as standard Gibbs free energy change $\left(\Delta \mathrm{G}^{0}\right)$, standard enthalpy change $\left(\Delta \mathrm{H}^{0}\right)$ and standard entropy change $\left(\Delta \mathrm{S}^{0}\right)$ were calculated by using the following equations:

$$
\ln K_{d}^{O}=\frac{\Delta \mathrm{S}^{O}}{R}-\frac{\Delta \mathrm{H}^{O}}{R T}
$$

(Equation 7)

where Kd: equilibrium constant

$$
\Delta \mathrm{G}^{0}=\Delta \mathrm{H}^{0}-\mathrm{T} \Delta \mathrm{S}^{0}
$$

(Equation 8)

$\Delta G^{0}, \Delta H^{0}$ and $\Delta S^{0}$ were calculated from a plot of $\ln \left(K_{d}\right)$ versus $1 / T$. The thermodynamic parameters of the phenol adsorption onto OP magnetic biochar are given in Table 3. $\Delta G^{0}$ value for both temperatures were found as negative that confirms feasible and spontaneous phenol adsorption onto OP magnetic biochar [34]. Mostly, $\Delta \mathrm{G}^{0}$ values for physi-sorption is between -20 and $0 \mathrm{~kJ} /$ mol and chemisorption is between -80 and $-400 \mathrm{~kJ} / \mathrm{mol}$ [34]. In this work, $\Delta \mathrm{G}^{0}$ was -47.9 and $-48.3 \mathrm{~kJ} / \mathrm{mol}$ that indicated that phenol adsorption with OP magnetic biochar is mainly dominated with physical adsorption. Addition to $\Delta G^{0}, \Delta H^{0}$ and $\Delta S^{0}$ are one another critical thermodynamic parameters which give information about adsorption process. In this study, negative $\Delta H^{0}$ value was obtained, which demonstrated the exothermic nature of the adsorption process [27]. As for $\Delta S^{0}$, positive value was found, so it can be explained by increment

\begin{tabular}{|c|c|c|c|c|c|c|c|c|c|}
\hline & \multicolumn{3}{|c|}{ Langmuir isotherm parameters } & \multicolumn{3}{|c|}{ Freundlich isotherm parameters } & \multicolumn{3}{|c|}{ Temkin isotherm parameters } \\
\hline & $\begin{array}{c}\mathrm{q}_{0} \\
\left(\mathrm{mg} \mathrm{g}^{-1}\right)\end{array}$ & $\begin{array}{c}\mathrm{K}_{\mathrm{L}} \\
\left(\mathrm{L} \mathrm{mg}^{-1}\right)\end{array}$ & $\mathrm{R}^{2}$ & $n$ & $\mathrm{~K}_{\mathrm{F}}$ & $\mathrm{R}^{2}$ & $\mathrm{~B}$ & $\begin{array}{c}A \\
\left(\mathrm{Lg}^{-1}\right)\end{array}$ & $\mathrm{R}^{2}$ \\
\hline $20^{\circ} \mathrm{C}$ & 3.88 & 0.0073 & 0.7093 & 0.68 & 0.0075 & 0.9533 & 2.89 & 0.05 & 0.8573 \\
\hline $40^{\circ} \mathrm{C}$ & 4.94 & 0.017 & 0.316 & 1.79 & 0.26 & 0.5326 & 1.10 & 0.18 & 0.5376 \\
\hline
\end{tabular}
in randomness at the solid-liquid interface during the adsorption process [27].

Table 1. Isotherms parameters for adsorption of phenol onto OP magnetic biochar at $20^{\circ} \mathrm{C}$ and $40^{\circ} \mathrm{C}$. 
Table 2. Kinetic parameters for adsorption of phenol onto OP magnetic biochar at initial phenol concentration.

\begin{tabular}{|c|c|c|c|}
\hline \multicolumn{4}{|c|}{ Pseudo-first order kinetic model } \\
\hline $\begin{array}{c}\mathrm{C}_{0} \\
\left(\mathrm{mg} \mathrm{L}^{-1}\right)\end{array}$ & $\begin{array}{c}\mathrm{q}_{\mathrm{e}} \\
\left(\mathrm{mg} \mathrm{g}^{-1}\right)\end{array}$ & $\begin{array}{c}k_{1} \\
\left(\mathrm{~min}^{-1}\right)\end{array}$ & $\begin{array}{c}r_{1}^{2} \\
0.9053\end{array}$ \\
\hline 60 & 4.58 & 0.0297 & \\
\hline \multicolumn{4}{|c|}{ Pseudo-second order kinetic model } \\
\hline $\begin{array}{c}\mathrm{C}_{0} \\
\left(\mathrm{mg} \mathrm{L}^{-1}\right)\end{array}$ & $\begin{array}{c}\mathrm{q}_{\mathrm{e}} \\
\left(\mathrm{mg} \mathrm{g}^{-1}\right)\end{array}$ & $\begin{array}{c}k_{2} \\
\left(\mathrm{~g} \mathrm{mg}^{-1} \mathrm{~min}^{-1}\right)\end{array}$ & $r_{2}^{2}$ \\
\hline 60 & 7.06 & 0.0086 & 0.9701 \\
\hline
\end{tabular}
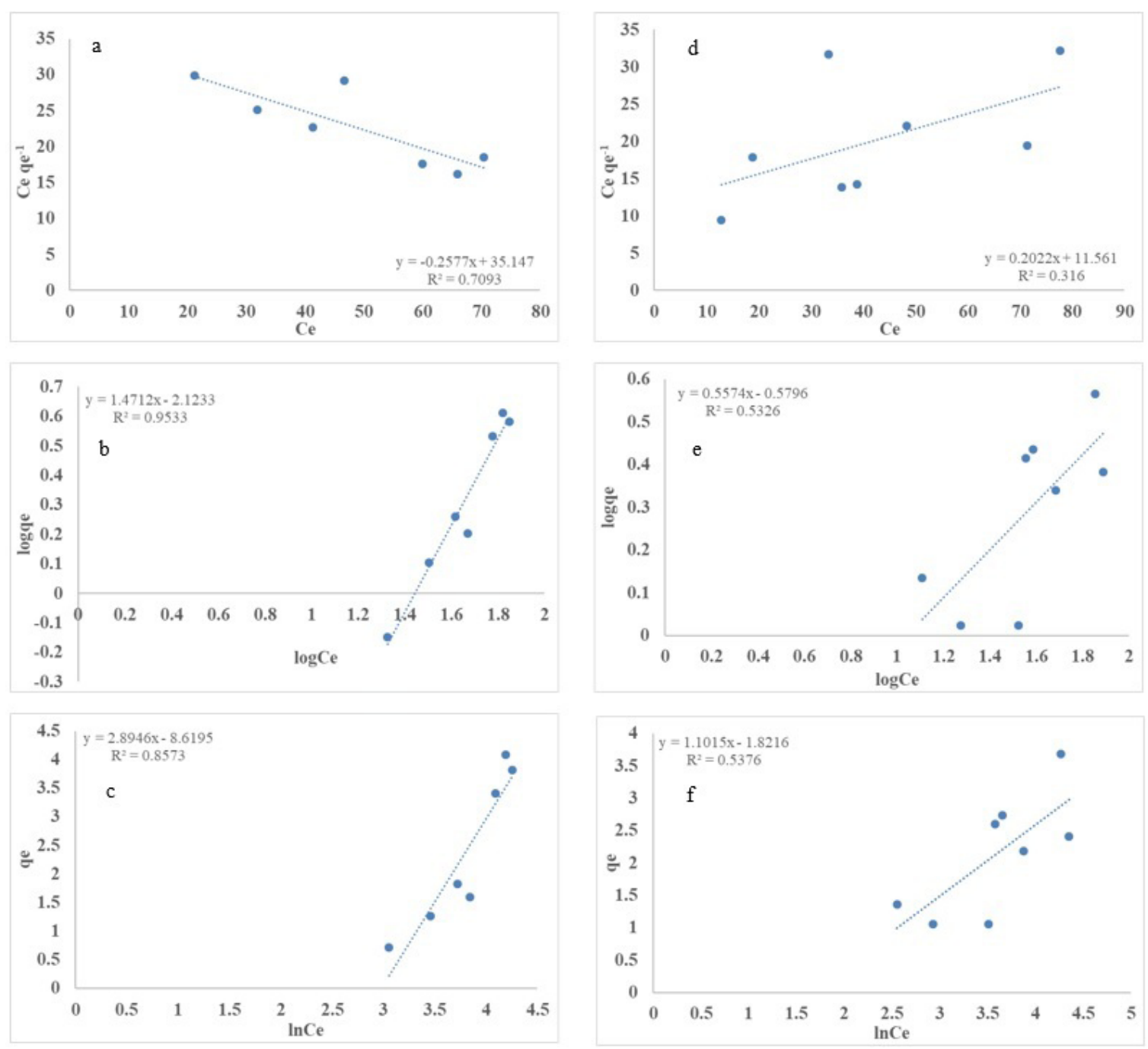

Figure 4. Langmuir isotherm (a), Freundlich isotherm (b) and Temkin isotherm (c) models at $20^{\circ} \mathrm{C}$ and Langmuir isotherm (d), Freundlich isotherm (e) and Temkin isotherm (f) models at $40^{\circ} \mathrm{C}$ for adsorption of the phenol onto OP magnetic biochar. 
142 G. Göktepeli et al. / Hacettepe J. Biol. \& Chem., 2021, 49 (2), 133-145

Table 3. Thermodynamic parameters of adsorption of phenol onto OP magnetic biochar.
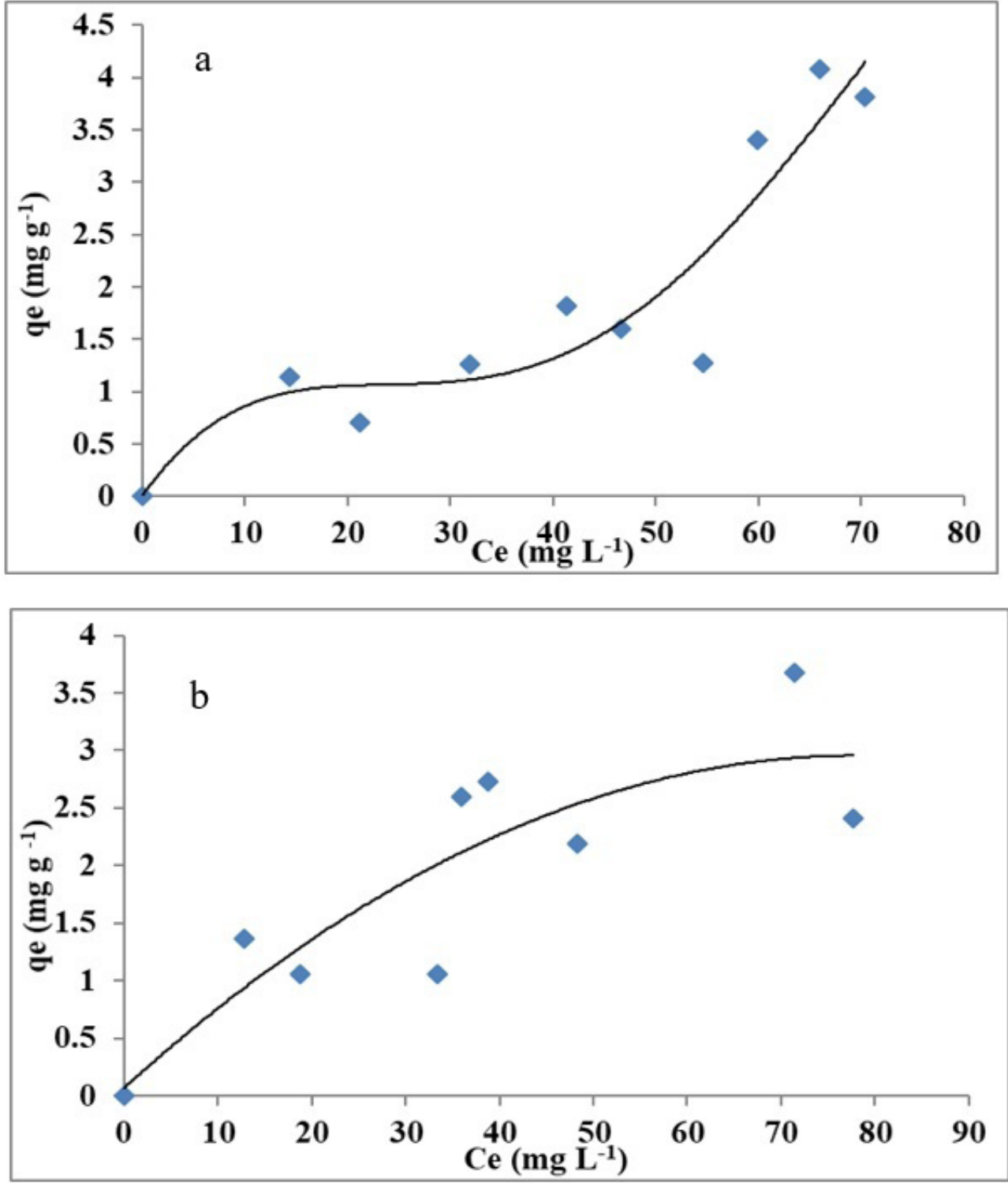

Figure 5. Equilibrium isotherms for phenol adsorption onto OP magnetic biochar at $20^{\circ} \mathrm{C}(\mathrm{a})$ and $40^{\circ} \mathrm{C}(\mathrm{b})$. 

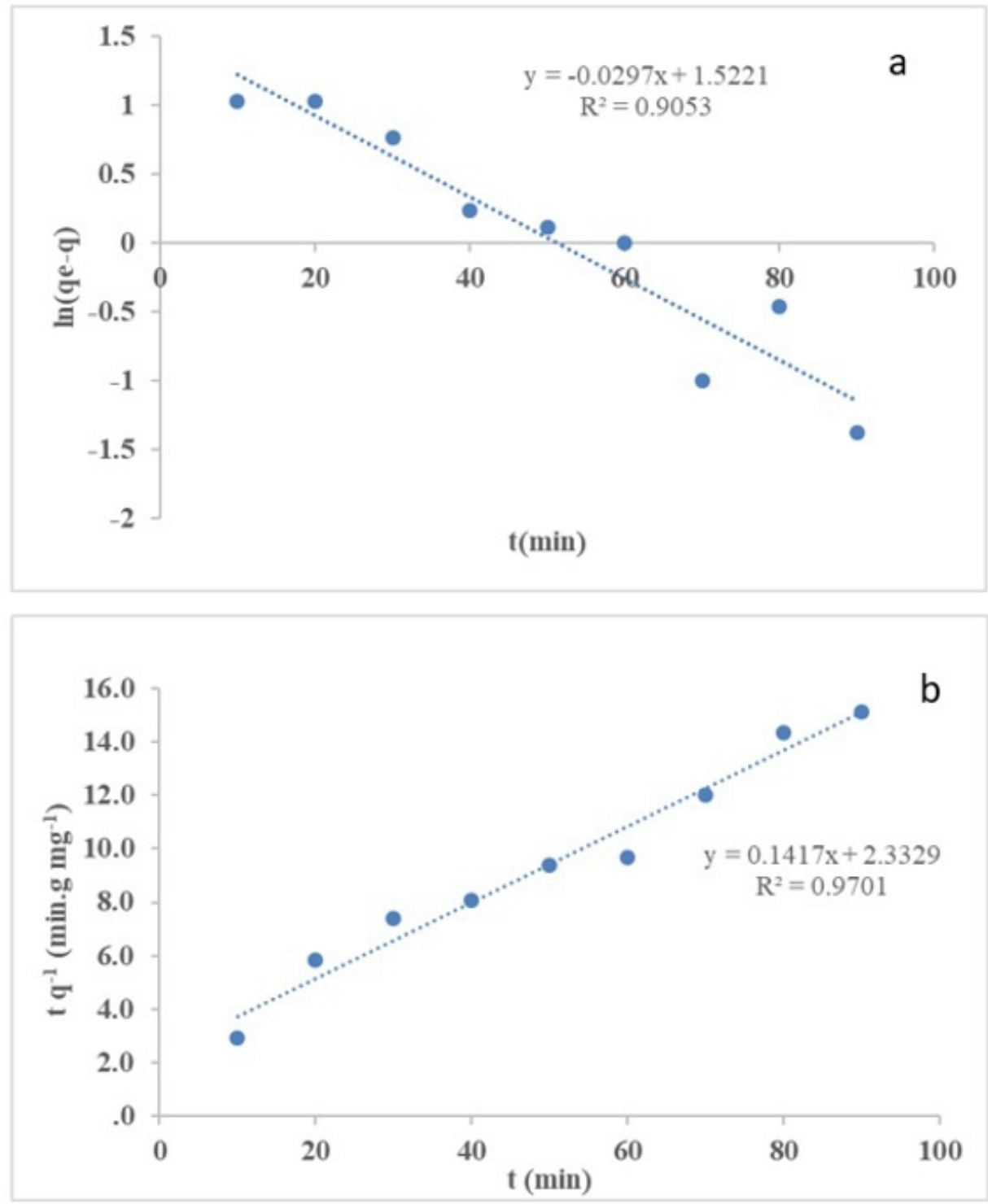

Figure 6. Pseudo-first order (a) and pseudo-second order (b) kinetics for the adsorption of phenol onto OP biochar. 
Adsorbent regeneration by desorption of phenol compounds from adsorbate can be achieved with several techniques, such as thermal regeneration, chemical regeneration, ultrasound and bioregeneration [35]. Among these techniques, chemical regeneration is much preferred by researchers in the studies about phenol desorption from pyrolysis chars [35-37]. Cancino et al. [36] conducted desorption experiments with water, ethanol and sodium hydroxide solutions and results showed that the highest recovery efficiency (10\%) belongs to ethanol solutions. In another study conducted by Liu et al [37], results showed that adsorbate can be used to adsorb phenolic compounds at least three cycles after desorption with sodium hydroxide. Similarly, Ozkaya [35] indicated that phenol can be recovered with sodium hydroxide and first-order kinetic model is more suitable as compared to diffusion model in the desorption study of phenolic compounds with sodium hydroxide. Therefore, it is recommended usage of chemical regeneration techniques for phenol desorption from OP magnetic biochars for the future studies.

\section{Conclusion}

The adsorption of phenol using OP magnetic biochar was investigated. The adsorption of phenol was found to be dependent on the $\mathrm{pH}$ solution, initial phenol concentration, contact time and temperature. The equilibrium adsorption data were best represented by the Freundlich isotherm, indicating adsorption on a heterogeneous surface and the adsorption capacity was found to be $7.06 \mathrm{mg} \mathrm{g}^{-1}$ at $20^{\circ} \mathrm{C}$. The results of the Freundlich isotherm model suggested that the adsorption process was dominated by physisorption mechanisms. The adsorption kinetic was described well by the pseudo-second-order model. The negative $\Delta H^{\circ}$ and $\Delta G^{\circ}$ values demonstrated that the adsorption was exothermic, feasibility and more spontaneous at lower temperatures. Moreover, adsorption capacity of phenol with OP magnetic biochar was found as comparable with the literature. To conclude, OP magnetic biochar can be stated among the effective alternatives for phenol adsorption since it provides ready separation and easy recycling from solution by low cost.

\section{References}

1. E.E.P. Ramírez, M. de la Luz Asunción, V.S. Rivalcoba, A.L.M. Hernández, C.V. Santos, Removal of phenolic compounds from water by adsorption and photocatalysis, Intech. Open, doi. org/10.5772/66895, (2017).

2. M. Uddin, M. Islam, and M. Abedin, Adsorption of phenol from aqueous solution by water hyacinth ash, ARPN J. Engineer. Appl. Sci., 2 (2007) 11-17.

3. A.A. Gami, Phenol and its toxicity: A short review, J. Environmen. Microbiol. Toxicol., 2 (2014).

4. N.A. Mohammed, R.A. Abu-Zurayk, I. Hamadneh, A.H. AlDujaili, Phenol adsorption on biochar prepared from the pine fruit shells: Equilibrium, kinetic and thermodynamics studies, J. Environ. Manage., 226 (2018) 377-385.

5. W. Shin, Adsorption characteristics of phenol and heavy metals on biochar from Hizikia fusiformis, Environ. Earth Sci., 76 (2017) 782.

6. Y. Nuhoglu, E. Malkoc, Thermodynamic and kinetic studies for environmentaly friendly $\mathrm{Ni}$ (II) biosorption using waste pomace of olive oil factory, Bioresour. Technol., 100 (2009) 2375-2380.

7. R. Canet, F. Pomares, B. Cabot, C. Chaves, E. Ferrer, M. Ribó, M. R. Albiach, Composting olive mill pomace and other residues from rural southeastern Spain, Waste Manag., 28 (2008) 2585-2592.

8. F.M. Pellera, A. Giannis, D. Kalderis, K. Anastasiadou, R. Stegmann, J.Y. Wang, E. Gidarakos, Adsorption of Cu (II) ions from aqueous solutions on biochars prepared from agricultural by-products, J. Environ. Manage., 96 (2012) 3542.

9. E. Malkoc, Y. Nuhoglu, M. Dundar, Adsorption of chromium (VI) on pomace an olive oil industry waste: batch and column studies, J. Hazar. Mater., 138 (2006) 142-151.

10. M. Martín-Lara, F. Pagnanelli, S. Mainelli, M. Calero, L. Toro, Chemical treatment of olive pomace: Effect on acid-basic properties and metal biosorption capacity, J. Hazar. Mater., 156 (2008) 448-457.

11. M. Erekici, Doğal adsorbanlarla (mısır koçanı, çam kozalağı, pirina, kireç) arsenik giderimi, Yüksek Lisans Tezi, Celal Bayar Üniversitesi Fen Bilimleri Enstitüsü, Manisa, (2009) 79.

12. H. Bozkan, Azo boyalarının zeytin atığı (pirina) kullanılarak adsorpsiyon metodu ile giderimi, Selçuk Üniversitesi Fen Bilimleri Enstitüsü, (2012).

13. S. Dağdelen, Remazol Brillant Blue $R$ Boyasının Sulu Çözeltiden Uzaklaştırılması için Zeytin Posasının (Pirina) Adsorbent Olarak Kullanımının Araştırılması, Kilis (2012).

14. L. Trakal, R. Šigut, H. Šillerová, D. Faturíková, M. Komárek, Copper removal from aqueous solution using biochar: effect of chemical activation, Arab. J. Chem., 7 (2014) 43-52.

15. Z. Elouear, J. Bouzid, N. Boujelben, R. B. Amor, , Study of adsorbent derived from exhausted olive pomace for the removal of $\mathrm{Pb}^{2+}$ and $\mathrm{Zn}^{2+}$ from aqueous solutions, Environ. Engin. Sci., 26 (2009) 767-774.

16. K.A. Komnitsas, D. Zaharaki, Morphology of modified biochar and its potential for phenol removal from aqueous solutions, Front. Environ. Sci., 4 (2016) 26. 
17. Y. Zhang, Z. Tang, S. Liu, H. Xu, Z. Song, Study on adsorption of phenol from aqueous media using biochar of Chinese herb residue, IOP Conference Series: Materials Science and Engineering, (2018) 022044

18. O. Xin, H. Yitong, C. Xi, C. Jiawei, Magnetic biochar combining adsorption and separation recycle for removal of chromium in aqueous solution, Water Sci. Technol., 75 (2017) 1177 1184.

19. D.H.K. Reddy, S.M. Lee, Magnetic biochar composite: facile synthesis, characterization, and application for heavy metal removal, Colloids Surf., A Physicochem. Eng. Asp., 454 (2014) 96-103.

20. M. Yap, N. Mubarak, J. Sahu, E. Abdullah, Microwave induced synthesis of magnetic biochar from agricultural biomass for removal of lead and cadmium from wastewater, J. Industr. Engin. Chem., 45 (2017) 287-295.

21. APHA, AWWA, WEF, Standard Methods for the Examination of Water and Wastewater, (2017).

22. I. Langmuir, The adsorption of gases on plane surfaces of glass, mica and platinum, J. Amer. Chem. Soc., 40 (1918) 1361-1403.

23. A. Dada, A. Olalekan, A. Olatunya, O. Dada, Langmuir, Freundlich, Temkin and Dubinin-Radushkevich isotherms studies of equilibrium sorption of $\mathrm{Zn}^{2+}$ unto phosphoric acid modified rice husk, IOSR J. Appl. Chem., 3 (2012) 38-45.

24. M. Rahimi, D. Wadi, M. Vadi, Langmuir, freundlich and temkin adsorption isotherm of captopril an ace inhibitor (or angiotensin-converting-enzyme inhibitor) is a pharmaceutical drug used for the treatment of hypertension by multi-wall carbon nanotube, Ind. J. Fund. Appl. Life Sci., 4 (2014) 933-937.

25. W.P. Cheng, W. Gao, X. Cui, J.H. Ma, R.F. Li, Phenol adsorption equilibrium and kinetics on zeolite X/activated carbon composite, J. Taiwan Inst. Chem. Eng., 62 (2016) 192-198.

26. O. Abdelwahab, N. Amin, Adsorption of phenol from aqueous solutions by Luffa cylindrica fibers: Kinetics, isotherm and thermodynamic studies, Egyp. J. Aquat.Res. 39 (2013) 215-223.

27. J. Sun, X. Liu, F. Zhang, J. Zhou, J. Wu, A. Alsaedi, T. Hayat, J. $\mathrm{Li}$, Insight into the mechanism of adsorption of phenol and resorcinol on activated carbons with different oxidation degrees, Colloids Surf., A Physicochem. Eng. Asp., 563 (2019) 22-30.
28. M. Erhayem, F. Al-Tohami, R. Mohamed, K. Ahmida, Isotherm, kinetic and thermodynamic studies for the sorption of mercury (II) onto activated carbon from Rosmarinus officinalis leaves, Amer. J. Anal. Chem., 6 (2015) 1.

29. Y.S. Al-Degs, M.I. El-Barghouthi, A.A. Issa, M.A. Khraisheh, G. M. Walker, Sorption of $\mathrm{Zn}(\mathrm{II}), \mathrm{Pb}$ (II), and $\mathrm{Co}$ (II) using natural sorbents: equilibrium and kinetic studies, Water Res., 40 (2006) 2645-2658.

30. S. Kayacan, Kömür ve koklarla sulu çözeltilerden boyar maddelerin uzaklaştırılması, Ankara Üniversitesi, Fen Bilimleri Enstitüsü, Kimya Anabilim Dalı, Yüksek Lisans Tezi (2007)

31. U. Soni, J. Bajpai, S. K. Singh, A. Bajpai, Evaluation of chitosan-carbon based biocomposite for efficient removal of phenols from aqueous solutions, J. Water Proc. Engin., 16 (2017) 56-63.

32. M. Ge, X. Wang, M. Du, G. Liang, G. Hu, J. SM, Adsorption analyses of phenol from aqueous solutions using magadiite modified with organo-functional groups: Kinetic and equilibrium studies, Materials, 12 (2019) 96.

33. Y.S. Ho, G. McKay, Pseudo-second order model for sorption processes, Process Biochem., 34 (1999) 451-465.

34. T. Liu, Y. Li, Q. Du, J. Sun, Y. Jiao, G. Yang, Z. Wang, Y. Xia, W. Zhang, K. Wang, Adsorption of methylene blue from aqueous solution by graphene, Colloid. Surf. B., 90 (2012) 197-203.

35. B. Özkaya, Adsorption and desorption of phenol on activated carbon and a comparison of isotherm models, J, Hazar. Mater., 129 (2006) 158-163.

36. M. Loredo-Cancino, E. Soto-Regalado, R. B. García-Reyes, F. D. J. Cerino-Córdova, M. T. Garza-González, M. M. AlcaláRodríguez, N. E. Dávila-Guzmán, Adsorption and desorption of phenol onto barley husk-activated carbon in an airlift reactor, Desalin. Water Treat., 57 (2016) 845-860.

37. X. Liu, Y. Wan, P. Liu, Y. Fu, W. Zou, A novel activated carbon prepared from grapefruit peel and its application in removal of phenolic compounds, Water Sci. Technol., 77 (2018) 25172527. 